\title{
Results of Fracture Mechanics Analyses of the Ederer Cranes in the Device Assembly
}

Edward N.C. Dalder

\section{RECEIVED \\ SEP 201996 \\ O\&TI}

August 21, 1996

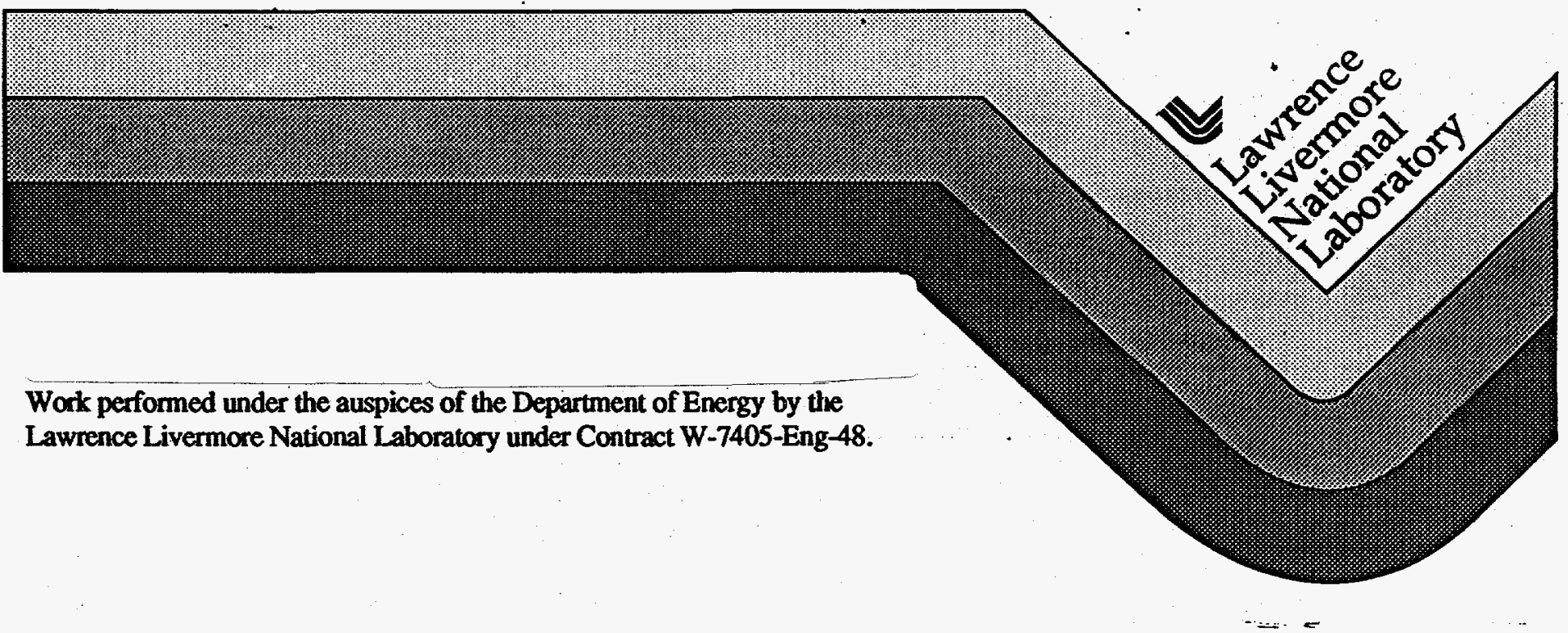

do DISTRIBUTION OF THIS DOCUMENT IS UNLIMTTED 


\section{DISCLAIMER}

This report was prepared as an account of work sponsored by an agency of the United States Government. Neither the United States Government nor any agency thereof, nor any of their employees, make any warranty, express or implied, or assumes any legal liability or responsibility for the accuracy, completeness, or usefulness of any information, apparatus, product, or process disclosed, or represents that its use would not infringe privately owned rights. Reference herein to any specific commercial product, process, or service by trade name, trademark, manufacturer, or otherwise does not necessarily constitute or imply its endorsement, recommendation, or favoring by the United States Government or any agency thereof. The views and opinions of authors expressed herein do not necessarily state or reflect those of the United States Government or any agency thereof. 


\section{DISCLAIMER}

Portions of this document may be illegible in electronic image products. Images are produced from the best available original document. 


\section{Manufacturing \& Materials Engineering Division}

August 21, 1996

TO:

A. M. Davito

FROM: $\quad$ Edward N.C. Dalder

SUBJECT: Results of Fracture Mechanics Analyses of the Ederer i Cranes in the Device Assembly Facility

Abstract: Per your verbal request, the suspect analyses were conducted on three critical locations on the lower flange of the load-beam of the Ederer 5 ton and 4 ton cranes in the D.A.F. Facility. Based on these results, it appears that:

1. Propagation of a $1 / 4^{\prime \prime}$ long flaw, previously undetected by nondestructive examination (NDE), to a length sufficient to cause structural failure of either flange, should not occur in at least 100 times the postulated operating scenarios for each crane;

2. Should each crane undergo annual inspection, any surface flaw with a length greater than $0.9^{\prime \prime}$ should be removed and repaired by qualified and approved repair procedures.

Introduction: Per A. Davito's verbal request, fracture mechanic analyses were performed for the highly-loaded lower flange on the Ederer 5 ton crane (Ederer Dwg. No. A14855) and Ederer 4 ton or "Polar" crane (Ederer Dwg. No.

A14937), using loads and stress information contained in Refs. 1-2. This work was done to determine (1) appropriate flaw-sizes for detection by nondestructive examination (NDE) methods during periodic inspection of these cranes, and

(2) appropriate inspection-intervals.

Procedure: First, Refs. 1-2 were reviewed, stress-information for the two cranes were obtained, and are summarized in Table 1. The maximum value of stress-component was selected as the stress-value to be used in the fracturemechanics calculations, to incorporate a measure of conservatism. Since the basis of these calculations was based on the growth of a pre-existing flaw under the action of cyclic stresses, it is appropriate to describe how such analyses are performed. 
Crack growth analysis is based on the similitude provided by the stress intensity factor $\mathrm{K}$, which provides a full description of the crack tip stress field, provided there is little plasticity. $K$ can be expressed as

$$
K=\sigma \sqrt{\pi \alpha} \beta
$$

where $a$ is the crack size (or half the crack size when the crack has two tips); sigma is the nominal (remote) stress, and beta a factor accounting for geometry. It should be emphasized that sigma is the nominal stress in a remote section not affected by the crack, as effects of the reduced area in the cracked section are accounted for in beta, a non-dimensional function of crack size and other geometrical parameters. Such beta values can be obtained from stress intensity handbooks such as Refs. 3-5.

The stress intensity provides a full description of the elastic crack tip stress field. If two cracks in the same material, but of different length and in different structural configuations, are subject to equal $\mathrm{K}$, then the stress fields at both crack tips are identical. Hence, both cracks behave in the same manner, i.e., show the same rate of growth. This leads to:

$$
\frac{d a}{d u}=f(\Delta k, R)
$$

where $\mathrm{da} / \mathrm{d} N$ is the rate of propagation, $N$ the number of cycles, $K_{\max }-K_{\min }$ the range of stress intensity in a load cycle, and $R=K_{\text {Min }} / K_{\text {HAK }}=\sigma_{M 1 N} / \sigma_{M A X}$ is the so-called "stress ratio".

According to the equation, every time a certain combination of $K$ and $R$ appears, the amount of crack extension is the same. The function $f(K, R)$ is obtained from crack growth tests on specimens in the laboratory. Data for many materials can be found in the literature, especially in Refs. 6-7.

The objective of crack growth analysis is to obtain a crack propagation curve for a crack in a structure. This requires integration of

$$
N=\int \frac{d a}{\mid d a / d N)}=\int \frac{d a}{f(\Delta x, R)}
$$

Since $f(K, R)$ is a complicated function, beta for the structural crack a complicated function of $a$, and the stress range is different in every load cycle, the integration has to be performed numerically, using a computer program such as "Fatcrak" (Ref. 8)

When different load cycles have different stress-ranges, similitude may no longer be provied by $K$. In such cases, $f(K, R)$ no longer provides the correct $\mathrm{da} / \mathrm{dN}$. This is called "load interaction". In most cases, the net load interaction effect is slower crack growth, which is called "crack retardation". Although load 
interaction may be explained qualitatively, there is no wholly satisfactory way to qualitatively account for the effect. The net load interaction effect is almost always a retardation.

The user has to specify the function $f(K, R)$. Several empirical equations are available for this function, none of which has a theoretical basis. The simplest curve fitting equation is known as the Paris equation (Ref. 9) which assumes a $\log -\log$-linear relation between $\mathrm{K}$ and $\mathrm{da} / \mathrm{dN}$ :

(4)

$$
\frac{d a}{d u}=C_{p}(\Delta K)^{n p}
$$

where $C p$ and $m_{p}$ are constants for a material. This equation ignores the effect of $R$, which is acceptable for our situation since $R=0$ (minimum load $=0$ ). See Appendix $A$ for additional information on determination of $C_{p}$ and $M_{p}$, the "Paris Law" constants for A36 steel at room temperature.

Hence, the input-information for operation of FATKRAK consists of:

1. The choice of flaw-configuration (Fig. 1), in our case, a semi-elliptical flaw with aspect-ratio of 0.25 , oriented on the bottom surface of the lower flange of the crane-beam for locations (or "points") 0 and 1 (Fig. 2b), or oriented on the top surface of the lower flange of the crane-beam for location 2 (Fig. 2a) (choosing such a flaw-configuration determines the stress-intensity expression

(Ref. 8)

(5)

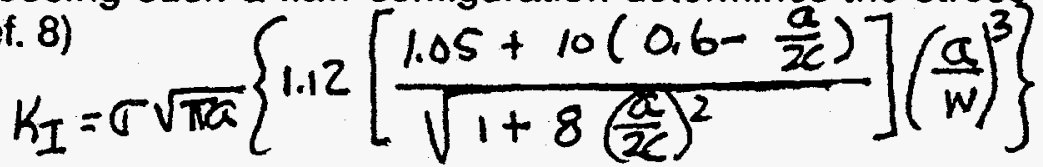

2. Initial flaw-size, ranging from flaw-depth values ("a") of $0.063^{\prime \prime}$ to $1.0^{\text {" }}$

3. Stress (O) values from Table 1;

4. Final defect-size, in terms of the critical value of flaw-depth, $a$, at which rapid, unstable failure occurs;

5. Paris-Law constants of $C_{p}=3.98 \times 10^{-12}$ in./cyc and $M_{p}=4.86$, from Appendix $A$; and

6. Width (288") and thickness (1.0" for the 5 ton crane, or $0.75^{\prime \prime}$ for the 4 ton crane of the flange) from Fig. 1.

A typical table of output is presented in Table 2, wherein progressively-larger flaw-dimensions are tabulated for increasing numbers of loading cycles. The results of 5-8 such runs, using increasing values of the initial flaw-size, as the input-parameter, are plotted in Fig. 3. (Additional plots for other load-cases and locations are contained in Appendix B). Information such as Fig. 3 may be used to set flaw-size units for safe operation, periodic inspection, and "Retirement for Cause"- based fracture safety as follows:

1. Determine the annual number of load-cycles (200-400 per Ref. 9 ) and total number of load-cycles $(12,000)$ at the "end-of-life", of 30 years (Ref. 10); 
2. Enter Fig. 3 at the indicated number of cycles, say 400 , and proceed vertically upward until the desired curve of "flaw dimension vs. cycles" is reached.

3. Proceed to the left until the "dimension of flaw" axis is reached, and read off the indicated flaw dimension for the chosen number of cycles of loading.

For the "initial flaw length", a quantity measurable by NDE, the value is 2.8 ".

The significance of this "initial flaw length", (2c), of $2.8^{\prime \prime}$ is that after 400 applications of a tensile stress of $11.6 \mathrm{ksi}$, rapid failure will occur. Proceeding in a similar manner with the computed information summarized in Figs. B1-B5, the information in Tables 3-4 was generated. Considering Table 3 first, it is seen that initial surface flaw-lengths on the order of 2.75-3.40 inches will cause failure in 200-400 cycles, a typical year's worth of operation. For a 30 year usage period, hereafter referred to as "a lifetime", initial surface flaw-lengths to cause failure drop to the order of 1.75-2.75".

Consider Table 4, wherein is summarized the number of loading-cycles needed to grow a small flaw, one with initial surface-length of $0.25^{\prime \prime}$, to sizes great enough to cause structural-failure of the lower flange. The initial surface-length

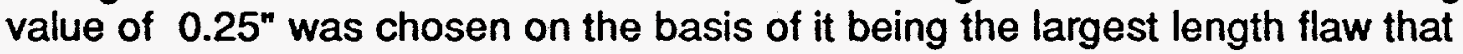
might not be detected by common NDE methods, such as magnetic-particle inspection or dye-penetrant methods, during periodic inspection of the cranes (Ref. 10). Note that, under such conditions, the predicted cyclic lives to failure are of the order $10^{6}-10^{8}$ cycles of load, or 104 to 1291 lifetimes of predicated crane usage. Hence, growth of a "reasonably small" undetected flaw to cause structural failure of the lower flange of either crane's beam is unlikely.

Discussion: Based on the information contained in Table 4, one could choose to make a case for "no periodic inspection" of the Ederer cranes' lower flanges, as the results contained in Table 4 represent "factors of safety" on cyclic-lives of greater than 100. However, since periodic inspections of other sub-systems of the cranes are likely to be performed on an annual basis (Ref. 10), i.e. every 400 cycles, detection of a flaw with a surface-length of $0.9^{\prime \prime}$ (half the surfacelength of a "fatal flaw") for the most highly-stressed location could be cause for retirement of the crane-beam. The choice of a factor of two reduction in flawlength is based on the A.S.M.E. Boiler and Pressure Vessel Code Section III (Nuclear) reduction factors on fatigue-performance (Ref. 11), i.e. the greater of a factor of 2 on strain-range (or stress-range) or a factor of 20 on cyclic life. In this treatment, the "strain-range; stress-range" parameter has been replaced by "initial flaw length". The choice of using half of the initial flaw-length of the most highly-stressed location; location 1 on the 4 ton crane, was done to introduce a single "go-no go" parameter rather than having 6 such values (3 per crane), that may cause confusion among inspectors. Should it be considered desirable by the D.A.F. operations management, detection of a flaw with a surface-length of $0.9^{n}$ might be made the point at which such a defect would be removed and 
replaced by suitable methods controlled by approved repair procedures. It is recommended that this issue by the subject of discussions with knowledgeable NTS, LANL, and LLNL personnel.

\section{Conclusions and Recommendations:}

1. Fracture-mechanics analyses of 3 critical-locations of the Ederer 4 ton and 5 ton cranes in the DAF Facility show that:

a. A semi-elliptical surface flaw, with an aspect ratio of 0.25 and an initial length of $0.25^{\prime \prime}$, oriented along the long direction of the lower flange of the load-beam(s), and not detected by NDE, is not expected to cause failure of the lower flange of either crane-beam in less than 100 times the postulated operational lives of either crane;

b. This conclusion could be used to support the choice of not performing periodic NDE of the crane-beam.

2. Since periodic surveillance inspections of the Ederer cranes will be performed on an annual basis, detection and removal of any flaw with a surface length of $0.9^{\prime \prime}$ (or greater) should be done using qualified and approved repairprocedures.

3. Consideration of flaw-configurations other than the one investigated ( a semi-elliptical flaw with an aspect-ratio of 0.25 , oriented along the long direction of the lower flange of the crane-beam), may be warrented.

For additional information, please contact the undersigned at ext. 2-7270.

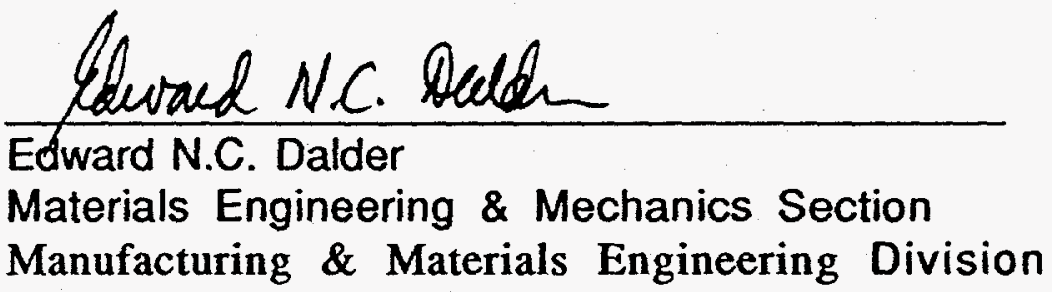

\section{Distribution:}

J. DIni, L-342

R. Riddle, L-342 
References:

1) L. Waiker (RSN) to A. Davito (LLNL), fax , "Ederer Five Ton Crane," Control No. 00260, 9/22/95

2) L. Walker (RSN) to A. Davito (LLNL), fax, " Ederer Four Ton Crane," Control No. AOBID301,12/7/95

3) D. Rooke and D. Cartwright, "Handbook of Stress Intensity Factors," Her Majesty's Stationary Office (UK), London, 1976

4) H. Tada, P. Paris, and G. Irwin, "The Stress Analysis of Cracks Handbook," Del Research Corp., 1973

5) Y. Murakam̆i (Editor), "Stress Intensity Factors Handbook," Pergammon Press, Vols., 1 \& 2, 1987, Vol. 3, 1992

6) W. F. Brown, Jr., "Aerospace Structural Metals Handbook,"CINDA/USAF CRDA Handbook Operation, Purdue University, Vols. 1-5, 1996 Edition

7) D. Skinn, J. Gallagher, A. Berens, P. Huber, J. Smith, "Damage Tolerant Design Handbook," WL-TR-94-4052, University of Dayton Research Institute, Volumes 1-4, Mary, 1994

8) D. Broek, "The Fracture Mechanic," User's Manual, A.S.M. International, 1986, pp. F5-F80

9) P. Paris, "The Growth of Fatigue Cracks Due to Variations in Load," Ph.D. Thesis, LeHigh University, 1962

10) A. Davito (LLNL), Personal Communication, 7/96

11) Anon, "Criteria of the ASME Boiler and Pressure Vessel Core for Design by Analysis in Sections III and VIII, Division 2," American Society of Mechanical Engineers, 1969 
Table 1: Stresses and Final Defect Sizes Used as Inputs to Fracture Mechanics Calculations

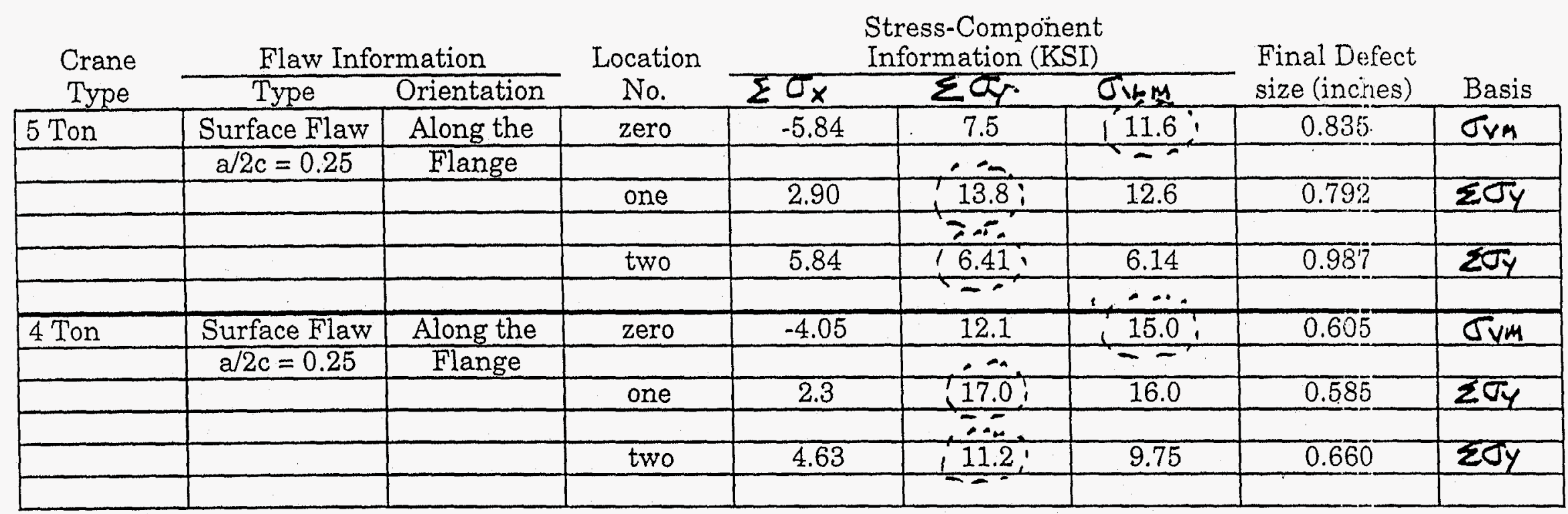

Notes:

1. $\Sigma \sigma_{X}=$ Total stress in $X$ direction (Fig. 1)

2. $\sum \sigma_{Y}=$ Total stress in $Y$ direction (Fig 1 )

3. $\sigma_{Y M}=$ Von Mises Stress $=\sqrt{\sigma_{x}^{2}+\sigma_{y}{ }^{2}-\sigma_{x} \sigma_{y}}$

4. Circled values of stress used as inputs to fracture mechanics calculation. 
RUN 71, 4 TON CRANE, LOCATION ONE, FLAW IS A SINGLE SURFACE CRACK WITH AN ASPECT-RATIO OF 0.25 AND IS ORIENTED ALONG THE LONG DIRECTION OF THE FLANGE, INITIAL FLAW-DEPTH IS 0.500", FINAL FLAW-DEPTH IS 0.585", WIDTH OF MEMBER IS 288", DEPTH OF MEMBER IS 0.75", SMAX IS $17 \mathrm{KSI}$, SMIN IS 0, SY IS $36 \mathrm{KSI}$

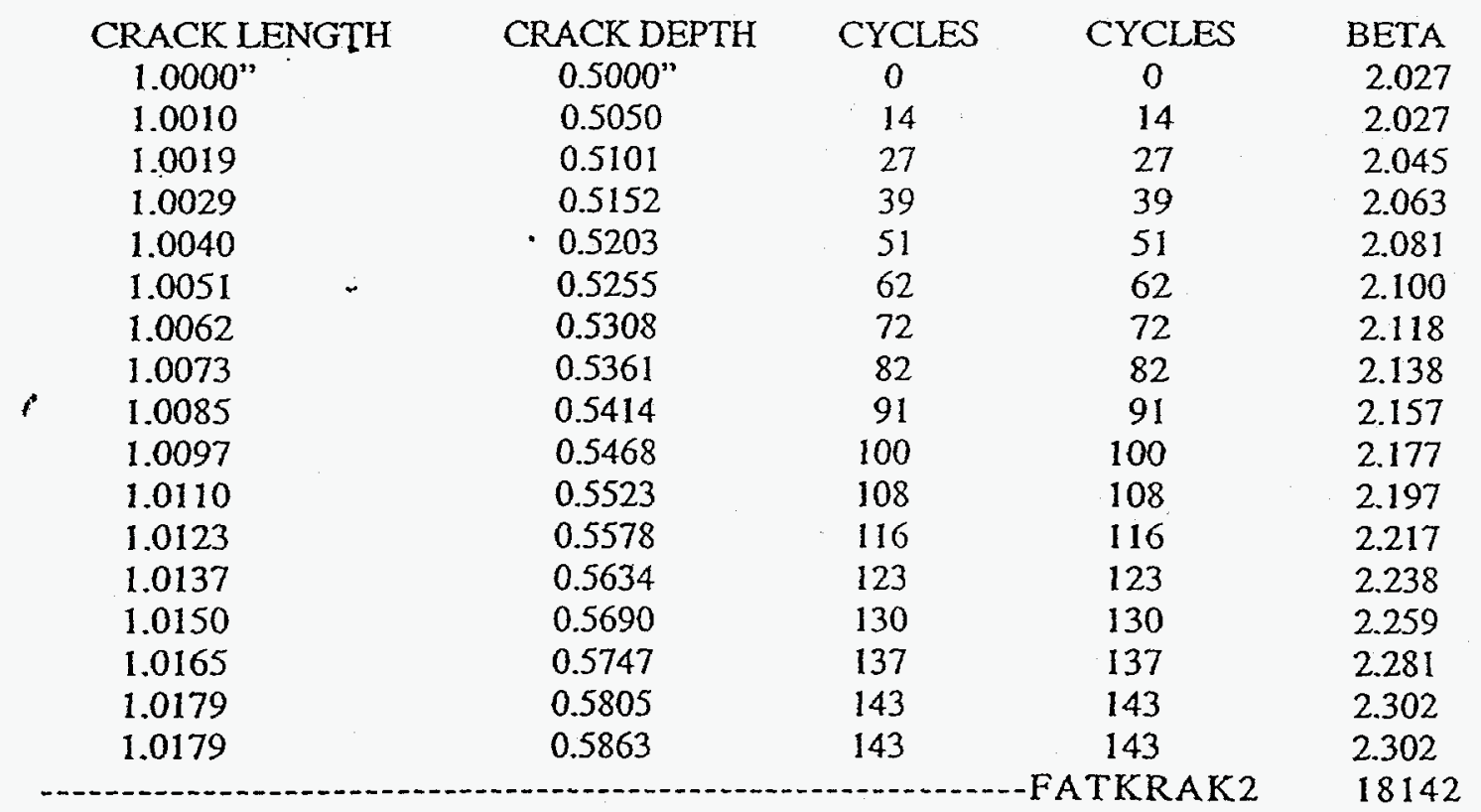

CRACK SIZE DEFINED AS THE CRACK DEPTH FROM SURFACE TO DEEPEST POINT PRESS 'ENTER' TO CONTINUE? 
Table 3:

Initial and Final Lengths of Semi-Elliptical Cracks (Aspect ratio $=0.25$ ) that will Cause Failure of the Lower Flange of the Ederer Five Ton and Four Ton Cranes when Cranes are Cyclically - Loaded

\begin{tabular}{|c|c|c|c|c|c|c|c|c|}
\hline \multirow{2}{*}{$\begin{array}{l}\text { Crane } \\
\text { Type }\end{array}$} & \multirow{2}{*}{$\begin{array}{l}\text { Location } \\
\text { No. }\end{array}$} & \multirow{2}{*}{$\begin{array}{l}\text { Range of } \\
\text { Stresses }\end{array}$} & \multicolumn{3}{|c|}{$\begin{array}{l}\text { (1) Initial Flaw-Length to } \\
\text { Cause Failure in Indicated } \\
\text { Number of Cycles }\end{array}$} & \multicolumn{3}{|c|}{$\begin{array}{l}\text { Final Flaw Length to } \\
\text { Cause Failure in Indicated } \\
\text { Number of Cycles }\end{array}$} \\
\hline & & & 200 & 400 & 12,000 & 200 & 400 & 12,000 \\
\hline 5 Ton & zero & $\begin{array}{l}0-11.6 \\
\text { KSI }\end{array}$ & $2.9^{\prime \prime}$ & $2.8^{\prime \prime}$ & $2.0^{\prime \prime}$ & $\begin{array}{c}3.0^{\prime \prime} \\
. \\
\end{array}$ & $3.0^{\prime \prime}$ & $2.1^{\prime \prime}$ \\
\hline & one & $0-13.8$ & $2.75^{\prime \prime}$ & 2.70 & 1.70 & 2.85 & 2.80 & 2.0 \\
\hline & two & $0-6.41$ & 3.40 & 3.30 & 2.75 & 3.85 & 3.70 & 2.9 \\
\hline 4 Ton & zero & $0-15$ & 2.05 & 2.0 & 1.3 & 2.15 & 2.1 & 1.5 \\
\hline & one & $0-17$ & 1.9 & 1.8 & 1.17 & 2.1 & 1.9 & 1.48 \\
\hline & two & $0-11.2$ & 2.4 & 2.2 & 1.6 & 2.5 & 2.4 & 1.9 \\
\hline
\end{tabular}

Notes:

(1) For a semi-elliptical surface-crack with an aspect-ration of 0.25 
Table 4: Number of Cycles needed to Grow a Semi-Elliptical Flaw with Aspect-Ratio of 0.25 and Initial Surface Length of 0.25 " to Structural Failure of the Lower Flange:

\begin{tabular}{|c|c|c|c|c|}
\hline $\begin{array}{l}\text { Crane } \\
\text { Type }\end{array}$ & $\begin{array}{l}\text { Location } \\
\text { No. }\end{array}$ & $\begin{array}{l}\text { Range of } \\
\text { Stresses }\end{array}$ & $\begin{array}{c}\text { Number of Cycles to } \\
\text { Grow } \\
\text { a Flaw(1) with Initial } \\
\text { Surface Length of } 0.25 " \\
\text { to } \\
\text { Structural Failure of } \\
\text { Flange }\end{array}$ & $\begin{array}{l}\text { Number of } \\
\text { Operational } \\
\text { Lives ( } 1 \text { life }= \\
12,000 \text { cycles) } \\
\text { to Grow Said Flaw } \\
\text { to Failure of Flange }\end{array}$ \\
\hline \multirow[t]{3}{*}{5 Ton } & zero & $\begin{array}{l}0-11.6 \\
\text { KSI }\end{array}$ & $8.673 \times 10^{6}$ cycles & 722 \\
\hline & one & $0-13.8$ & $3.727 \times 10^{6}$ & 310 \\
\hline & two & $0-6.41$ & $1.55 \times 10^{8}$ & 1291 \\
\hline \multirow[t]{4}{*}{4 Ton } & zero & $0-15$ & $2.292 \times 10^{6}$ & 191 \\
\hline & one & $0-17$ & $1.254 \times 10^{6}$ & 104 \\
\hline & two & $0-11.2$ & $9.549 \times 10^{6}$ & 796 \\
\hline & & & & \\
\hline
\end{tabular}

Notes:

(1) Initial flaw is a semi-elliptical surface crack with an aspect ratio of 0.25 and a surface-length of 0.25 " 
FIGURE 2
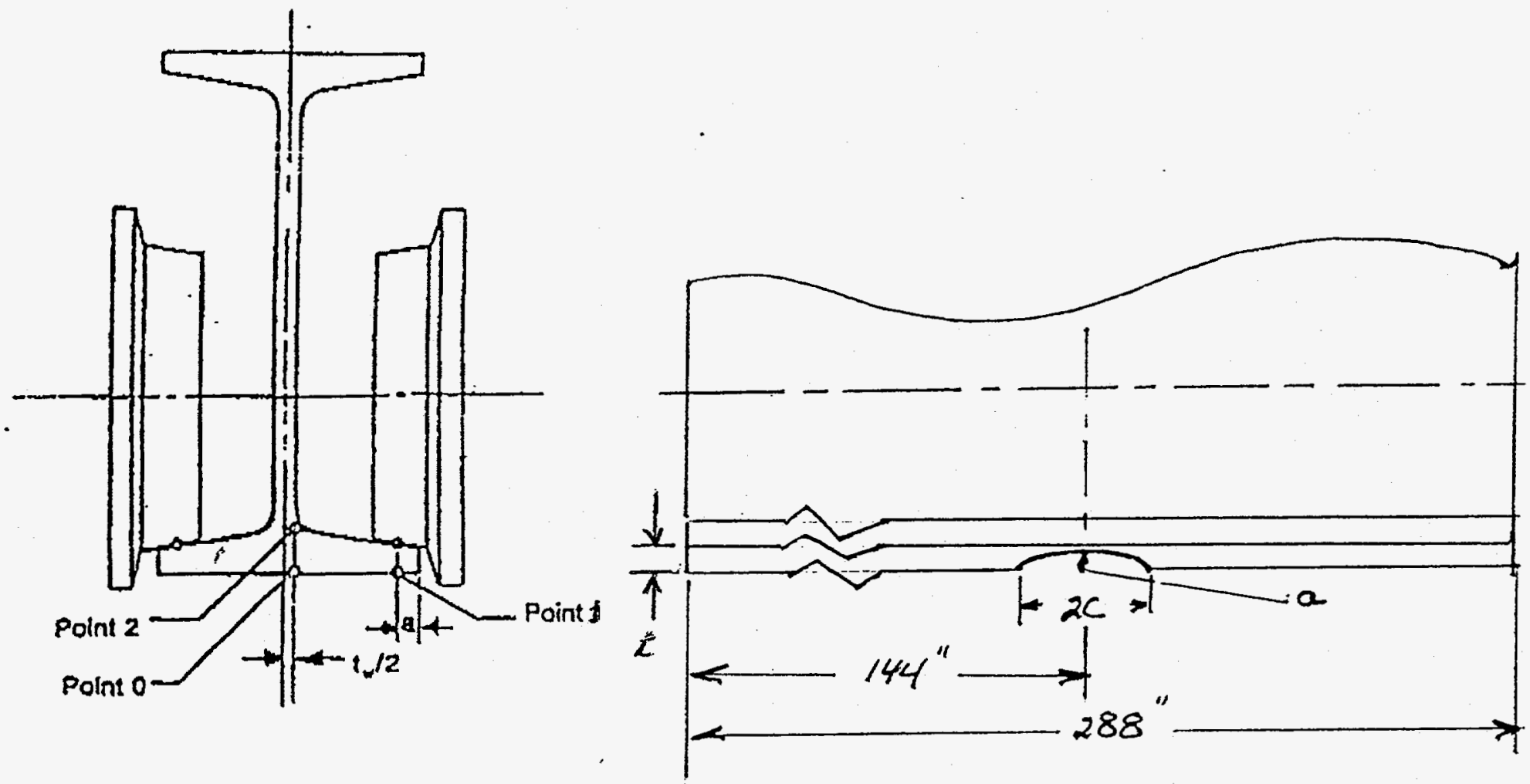

(A) CROSSECTION OF BEAM, SHOWING LOCATIONS OF LOAD-APPLICATION

(B) LOCATION OF SEMI-ELLIPTICAL SURFACE CRACK IN FLANGE OF BEAM

\section{LOCATIONS OFLOADARTHICATION}




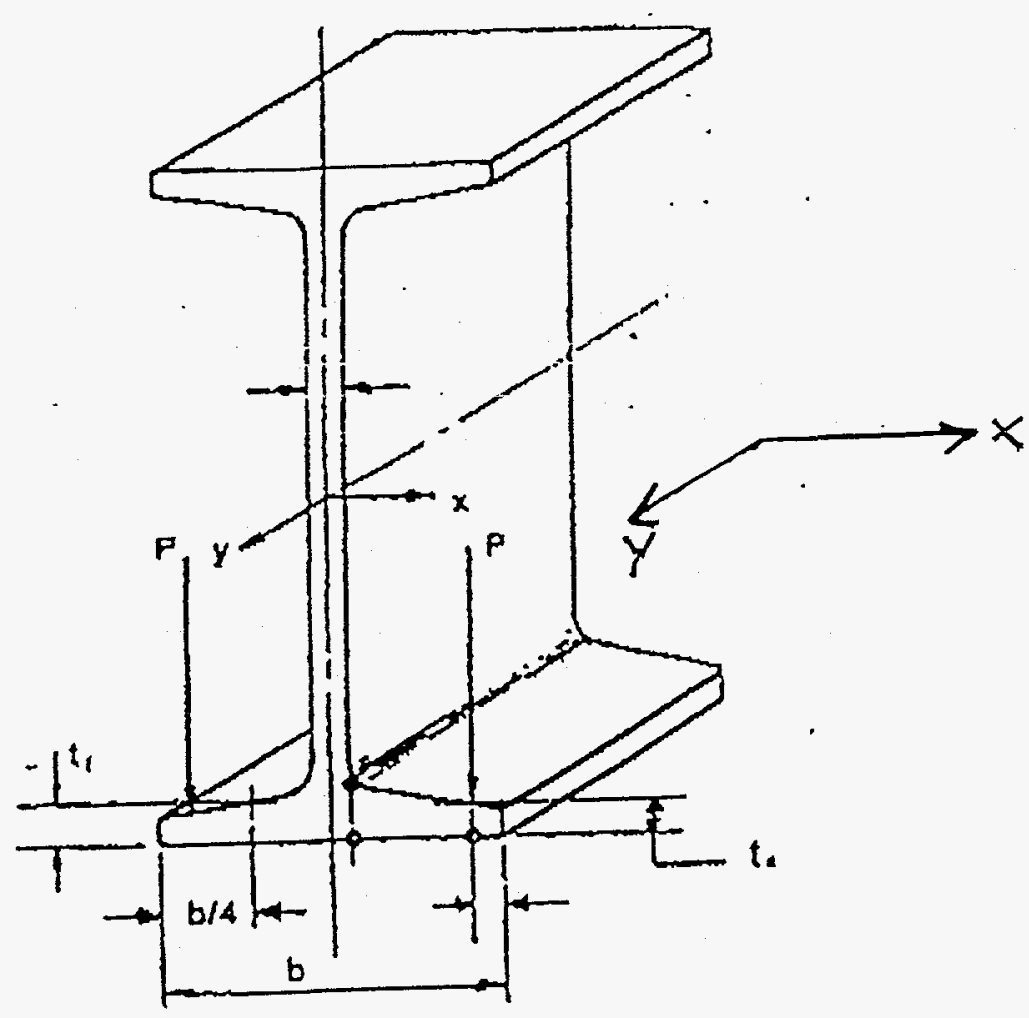

(A) SCHEMATIC OF CROSSECTION OF BEAM

$\begin{array}{cc}\text { CRANE TYPE } & \mathrm{t} \\ 5 \text { TON } & 1.00 \\ 4 \text { TON } & 0.75\end{array}$

FIGURE 1 
DIMENSTION of FAW (INCHES)

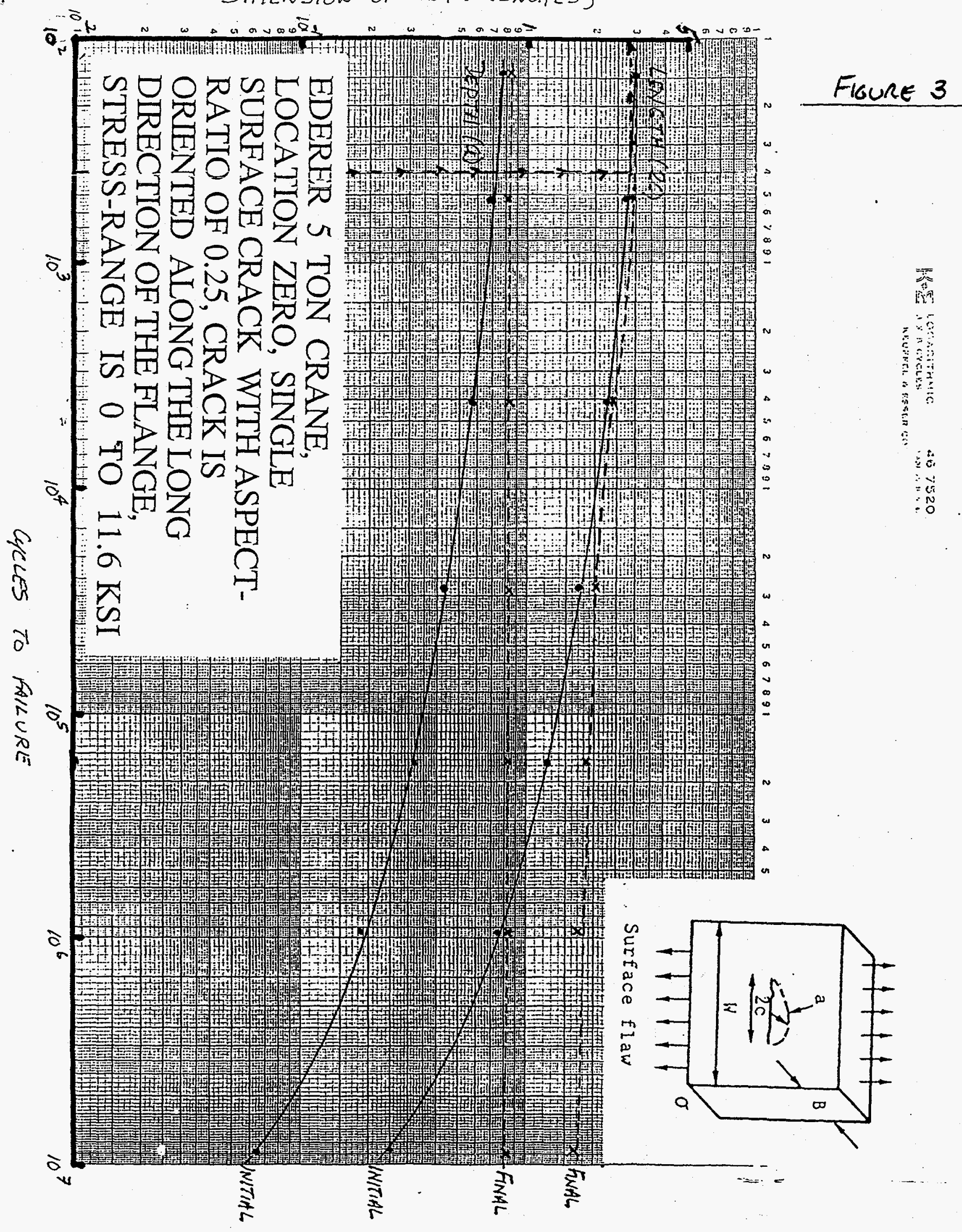




\section{Appendix A - Construction of Materials Design-Allowables for ASTM A-36 Steel Used in Construction of the Ederer Cranes in the Device Assembly Facility (D.A.F.)}

\section{Intreduction:}

Steel supplied to recent version of ASTM specification A-36 (A-36-89, Ref. A-1) falls in the category of a "plain carbon", or carbon-steel, and is supplied as rolled structural shapes (angles, channels, and tees, for example), plates, and bars of structural quality for use in riveted, bolted, or welded construction. It is seldom supplied with any type of fracture-toughness requirements. In plate up to 4" thick supplied to earlier versions of ASTM A-36 (Ref. A-2), material could be supplied without having had excess dissolved oxygen removed by liquidstate deoxidation with $\mathrm{Si}, \mathrm{Al}$, (or both) to form insoluble particles of oxides called "inclusions". Such steels are called "Rimmed Steels". Partial liquid-state deoxidation is also allowable in plates up to $3 / 4^{\prime \prime}$ thick, and steel so treated is referred to as "semi-killed steel". Plates above 3/4" thick supplied to Ref. 2, and plates above 2" thick supplied to earlier versions of ASTM A-36, are supplied in the fully-deoxidized or "fully-killed" condition. The reasons for the concern about the deoxidation-state of A-36 steel are: (1) The higher the dissolved (soluble) oxygen-content in A-36 steel, the higher is the toughness-transition temperature and the lower will be the upper shelf energy, a measure of ductile fracture-toughness (Ref. A-3); and (2) The higher the inclusion-content (caused by less than complete liquid state deoxidation), the greater will be the directional-dependence of fracture-toughness in the finished product, since large numbers of the oxide inclusions will be elongated in the primary rollingdirection and will serve as semi-continuous paths of easy crack growth in this direction during mechanical loading (Ref. A-3).

How the steel used in manufacture of the cranes D.A.F. were made and whether these heats of steel were evaluated for fracture-toughness is of importance for two reasons:

1. Both LLNL Mechanical Engineering Design Safety Standards (Ref. A-4) and the NTED Design Guide (Ref. A-5) mandate the use of a "lower bound plane-strain fracture-toughness" $\left(K_{I_{C}}\right)$ of $25 \mathrm{ksi}$ (Th. for uncharacterized steels; and 2. The arbitrary use of such a low $K_{1 c}$ value for fracture-mechanics-based analyses of the fracture safety of critical components in D.A.F. could result in imposition of expensive and unreasonable restrictions on operation and periodic inspection of the D.A.F. cranes.

Review of documentation (Ref. A-6) submitted with the stress-analyses of the D.A.F. cranes indicated that the A-36 steel used in the manufacture of the D.A.F. cranes was fully deoxidized, and both charpy $v$-notch impact and (in a few cases), dynamic tear tested. Hence, use of plane-strain fracture-toughness values greater than the aforementioned "lower-bound value" is appropriate. The results of a literature search on the variation of $K_{1 C}$ with temperature for $A$ - 
36 (and similar) steels (Refs. A-7 to A-12) is presented in Figure A-1, where the "lower bound" $K_{\mathrm{Ic}}$ values for this material at and slightly below room temperature is $45-47 \mathrm{KSI}$ lin. Accordingly, a $\mathrm{K}_{\mathrm{IC}}$ value of $45 \mathrm{KSI}$ (in was adapted for use in the subject analyses.

A similar search for fatigue-crack-growth-rate (F.C.G.R.) information yielded the information (Refs. A-13 to A-19) in the form that is plotted in Eqn (A-1) and is presented in Figures A-2 through A-4.

$$
\begin{aligned}
& (A-1) \text { F.C.G.R. }=\frac{d a}{d n}=C(\Delta K) \\
& \text { where } \mathrm{da}=\text { incremental increase in crack-length } \\
& \mathrm{dn}=\text { incremental increase in number of load-cycles } \\
& \text { çm = material-constants that are fixed for constant } \\
& \text { 1. material, temperature, and ratio of minimum to } \\
& \text { maximum load ("R") } \\
& \mathrm{K}=\text { Range of stress intensity }=\mathrm{K}_{\max }-\mathrm{K}_{\min } \text {, where } \\
& \sigma_{\text {Max }}-\sigma_{\text {min }} \\
& \sigma=\text { applied stress } \\
& a=\text { characteristic dimension of crack (or flaw), it may } \\
& \text { be depth, surface length or half of the surface } \\
& \text { length. } \\
& \beta=A \text { parameter that depends on the geometric } \\
& \text { constraints of the problem; in particular any } \\
& \text { angular relationships between the load (or } \\
& \text { loads) and direction of crack-extension, as well as } \\
& \text { the geometry of the structure. }
\end{aligned}
$$

Examination of Figs. A-2 through A-4 indicates that the highest F.C.G.R. data-set is that for hot-rolled A-36 steel tested under conditions of $R=0$; i.e.

(A-2) $\frac{d a}{d n}=3.98 \times 10^{-12}(\Delta K)^{4.86}$

which is the F.C.G.R. expressed selected for use in the fatigue crack growth analyses.

\section{References:}

A-1 Anonymous, "Standard Specification for Structural Steel", Specification A36/A36M-89, American Society for Testing and Materials, Annual Book of ASTM Standards, Vol. 03.01, 1990.

A-2 B.M. Kapadia, U.S.S. Division of U.S.X. Corporation, Personal Communication, October 1990.

A-3 G.E. Dieter, "Mechanical Metallurgy", 3rd Edition, McGraw-Hilt; New York, 1986, Pp. 479-81. 
A-3 G.E. Dieter, "Mechanical Metallurgy", 3rd Edition, McGraw-Hill, New York, 1986, Pp. 479-81.

A-4 J.J. Scott, "Design Säiety Standards....Aechanicai Engineering Section 5.4. "Fracture Critical Components", Pg. 14, Sept. 15, 1995.

A-5 A.M. Davito, "NTED Design Guide", Rpt. M-186, Rev. 1, Chapter 3, "Implementation of Fracture Control:, Pg 3-3, May 1993.

A-6 R. Henning (Bechtel-Nevada) to A. Davito, "Internal Transmittal of Mill Test Reports", July 1995.

A-7 R. Pandey, J. Harris, and S. Bancrjee, "Fracture Behavior of DynamicallyLoaded Ship Building Plate Material," Engineering Fracture Mechanics, 6, 1974, Pp 105-118.

A-8 W. Wilson, W. Clarke, Jr. and E. Wessel, "Fracture Mechanics Technology for Combined Loading and Low-To-Intermediate Strength Metals," U.S. Army Tank Automotive Command, Final Technical Report, 11/18/68, Pp1426

A-9 F. Burdekin, R. Dolby, and G. Egan, "Fracture Initiation in Welded Joints of Ferritic Steels" in "Second Conference on the Significance of Defects," The Welding Institute, Paper 15, 1968, Pp 180-191.

A-10 E. Ripling, "Fracture Properties of a Cold-Worked Mild Steel," in "Fracture Toughness and Slow-Stable Cracking," ASTM S.T.P. 559, American Society for Testing and Materials, 1974, Pp 59-73.

A-11 M. Kaseem, "Fracture Toughness and Its Determination," Engineering Fracture Mechanics 10 1978, Pp 591-608.

A-12 J. Baldwin, Jr. and J. Cooper, "Relocation of Toughness Test Values to Fatigue Cracking in Bridges, "Report FHWA/Mo-78/2, University of MissouriColumbia, August 1981, Pp. 21-30

A-13 J. Barsom, "Fatigue Crack Propagation in Steels of Various Yield Strengths," Journal of Engineering for Industry (A.S.M.E. Tranasactions, Series B), 93 (4), Nov. 1971

A-14 W. Wilson, W. Clark, Jr., and E. Wessel, "Fracture Mechanics Technology for Combined Loading and Low-To-Intermediate Strength Metals," Technical Report No. 10276 (final) to U.S. Army TACOM, November 18, 1968, Pp. 17-19

A-15 J. Baldwin, Jr. and J. Cooper, "Relation of Toughness Test Values to Fatigue Cracking of Bridges," Report No. FHWAMo-78/2, to Missouri Highway and Transportation Department, August 1981, Pp. 32-36 
A-16 R. Stephens, P. Benner, G. Mauritzson, and G. Tindall, "Constant and Variable Amplitude Fatigue of Eight Steels" Journal of Testing and Evaluation, Z (2), March 1979, Pp. 68-81

A-17 N. Yadzani and P. Albrecht, 'Crack Growth Rates of Structural Steel in Air and Aqueous Environments, "Engineering Fracture Mechanics, 32(6), 1989, Pp. 997-1007

A-18 G. Rading, The Effect of Welding on the Fatigue Crack Growth Rate in a Structural Steel," Welding Journal, 72 (7), July 1993, Pp. 307s -312s

A-19 H. Iguchi, K. Tanaka, and S. Taira, "Failure Mechanisms in Impact Fatigue of Metals," Fatigue of Engineering Materials and Structures, 2 1979, Pp. 165-176 


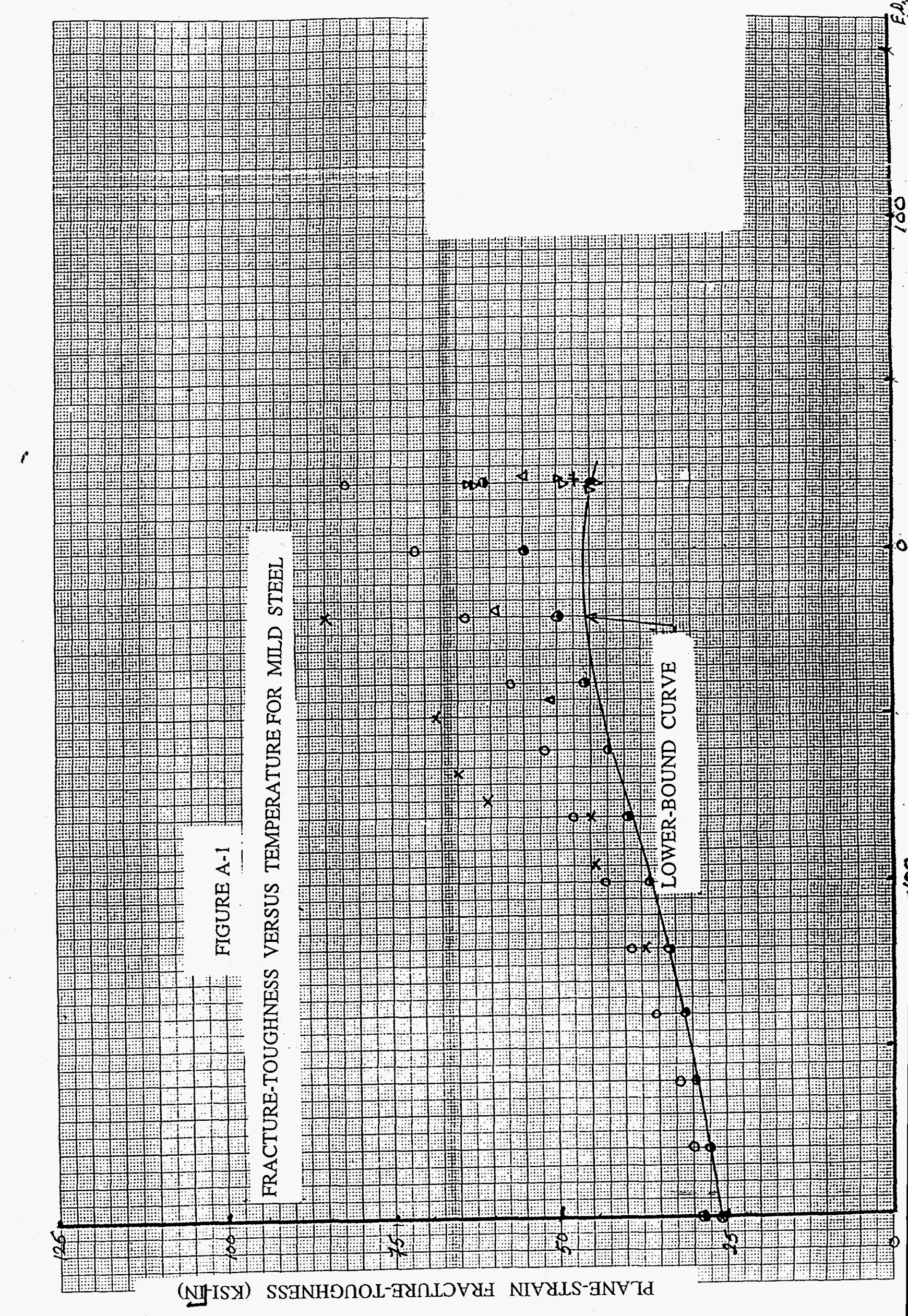




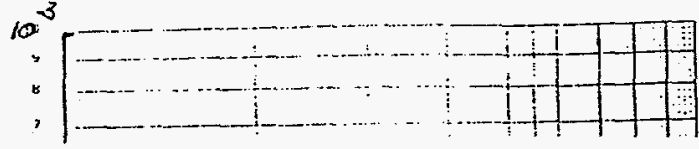

FIGURE A-2

ROOM-TEMPERATURE FATIGUE-CRACK GROWTH BEHA VIOR OF A.S.T.M. A-36 STEEL AND EQUIVALENT MATERIALS

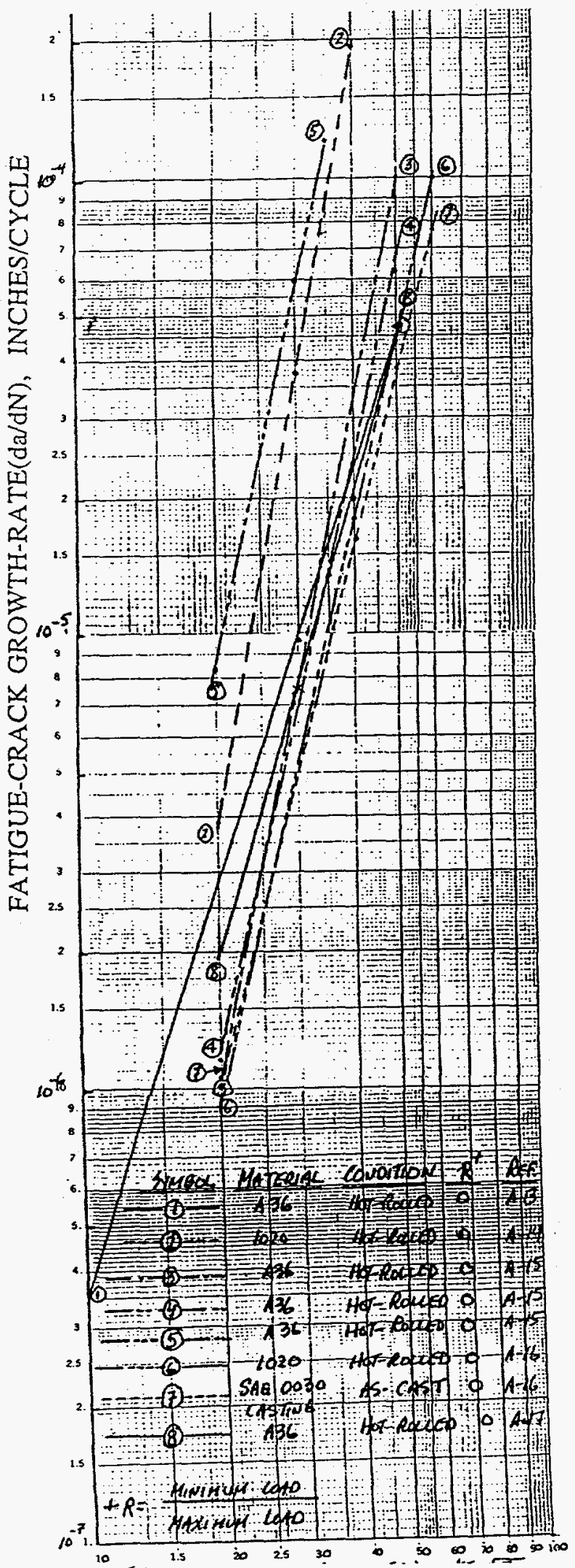

E.0.

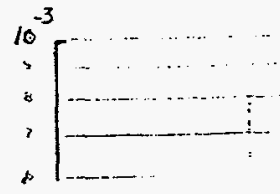

FIGURE A-3

EFFECT OF LOAD-RATIO ON ROOMTEMPERATURE FATIGUE-CRACK

GROWTH BEHAVION OF A.S.T.M. A.36 STEEL AND EQUIVALENT MATERIALS



STRESS-INTENSITY RANGE( 


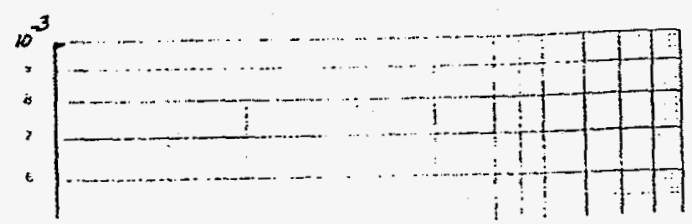

FIGURE A-4

EFFECT OF FUSION-WLLDNG ON TUE ROOM TEMPERATURE FATIGUE-CRACK GROWTH-RATE OF A.S.T.M. A-36 STEEL AT FLXED LOAD-RATIOS

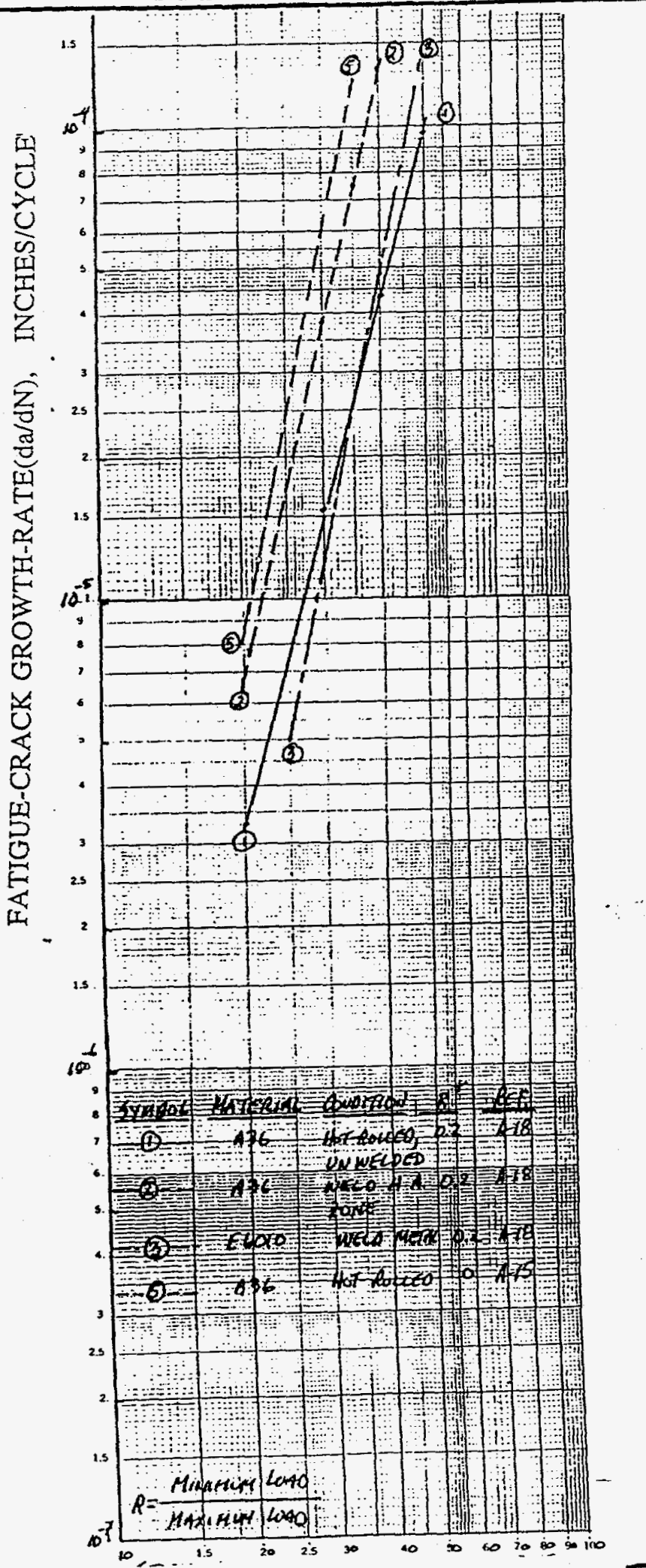

STRESS-INTENSITY RANGE( $\Delta \mathrm{K}), \mathrm{KSI}$ IIN 
Appendix $\bar{B}$ Pilots of Fiaw-Dimension Versus Cycles io Failure for Ederer Cranes 
DIMENSION OF FLALU (INCHES)

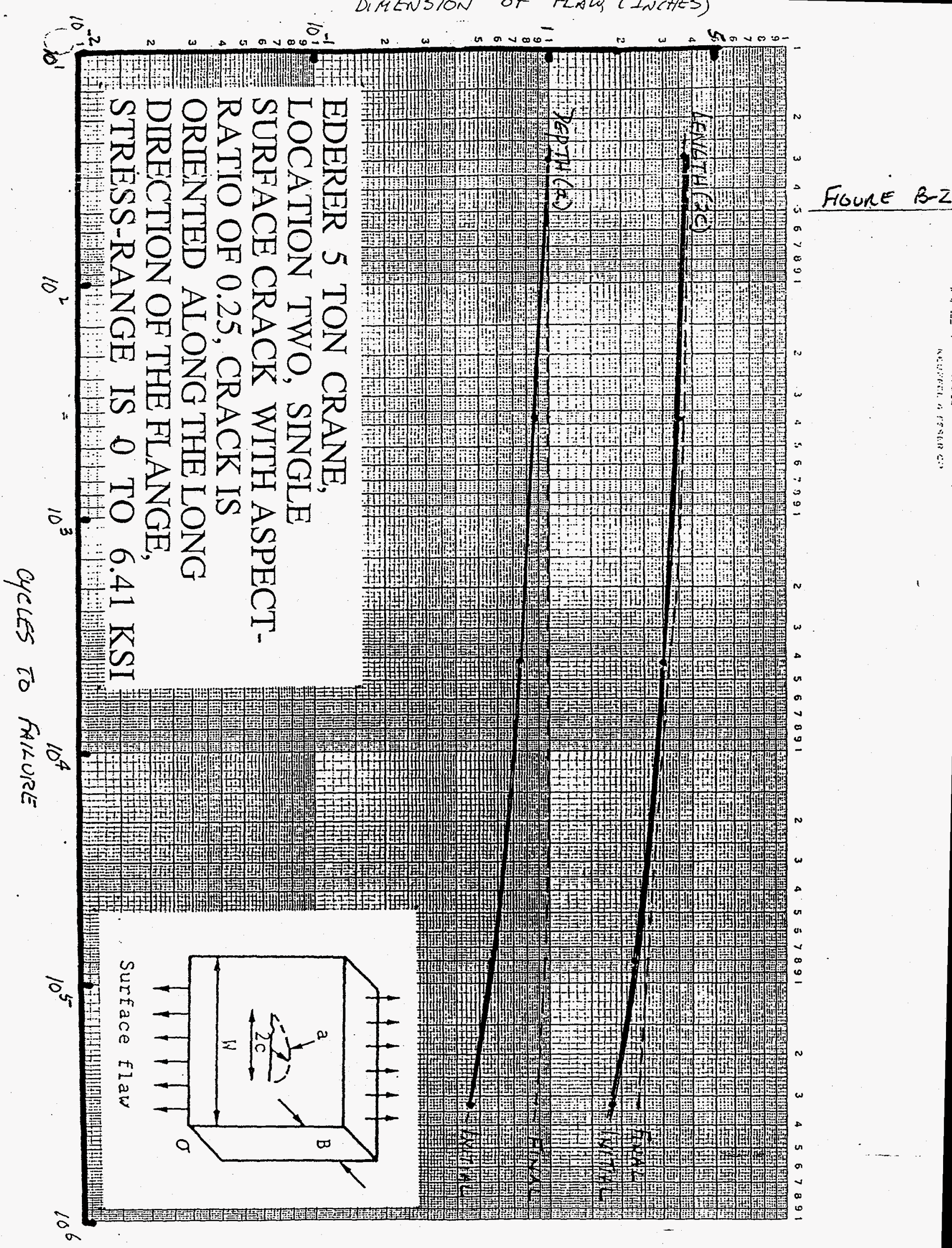




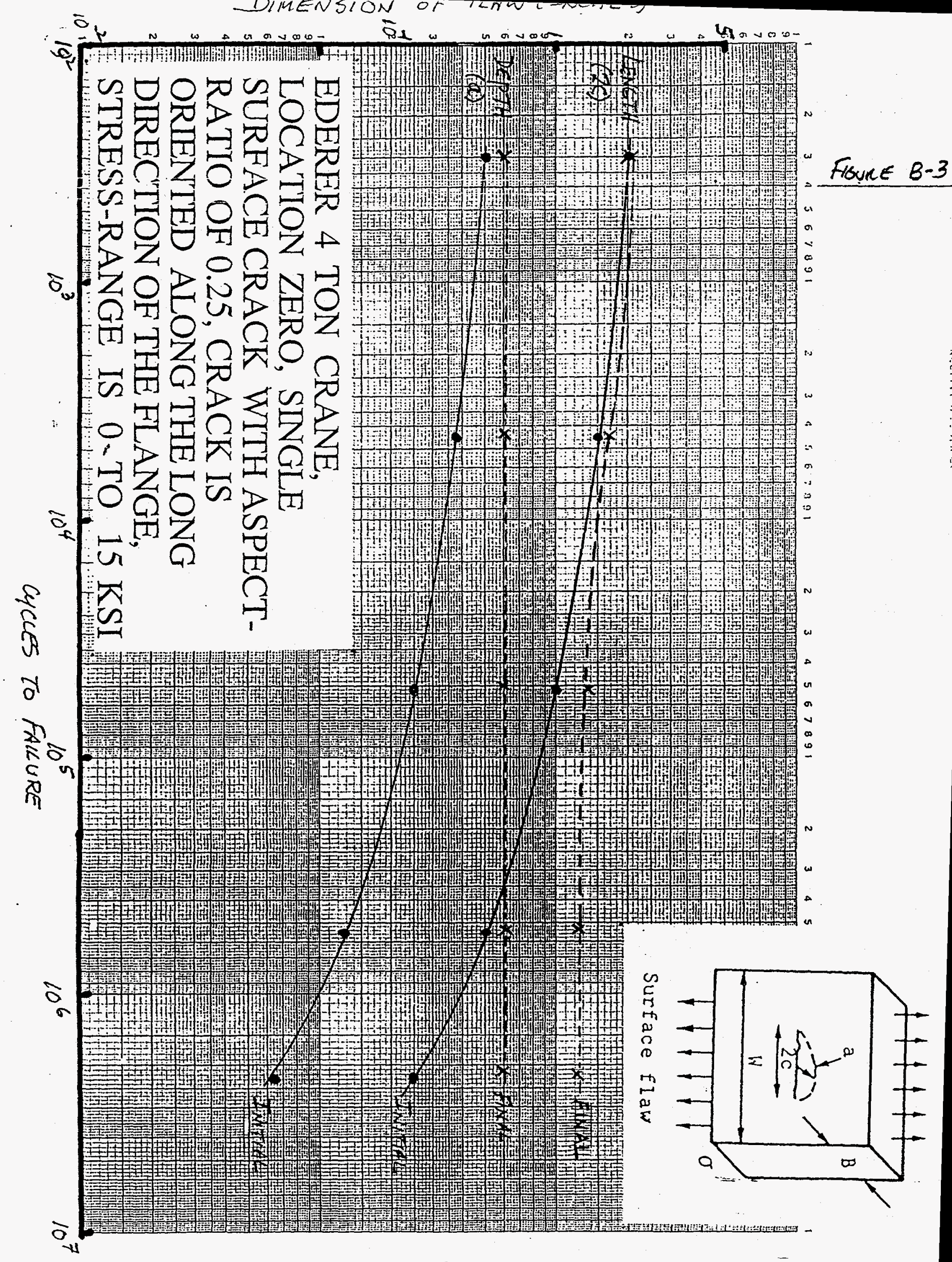



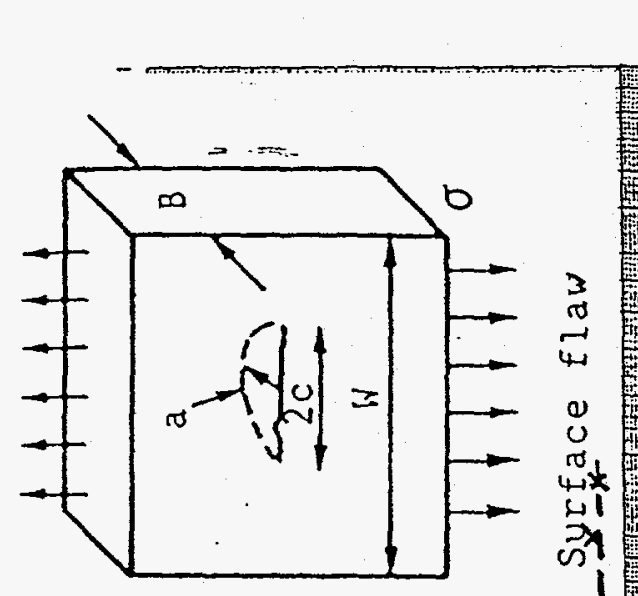

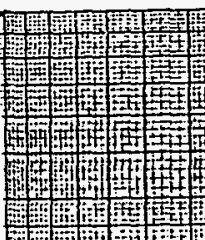

n

?

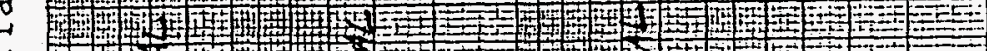

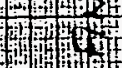
$+3+m^{2}$ $+7+1$ (it+1


$+$

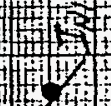

1 (1)

1 440 은

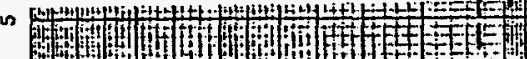

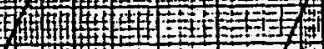
Fat

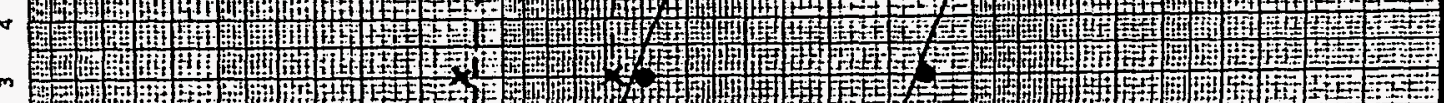



$\sim$

(3)

m)

(4) (1) (1)

o

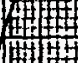

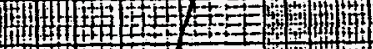

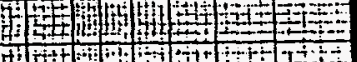

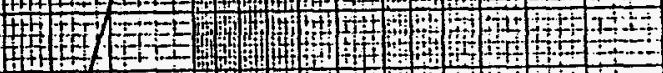

n

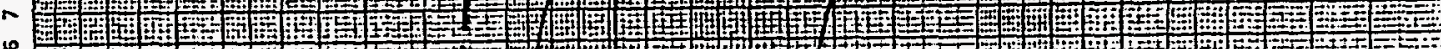

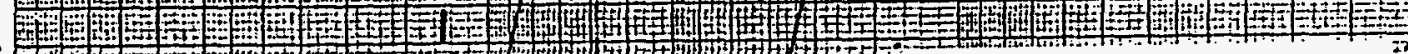

s

-

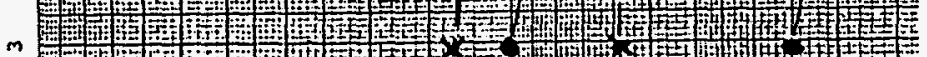

(3)

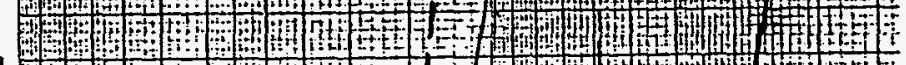

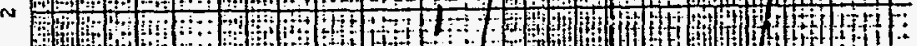

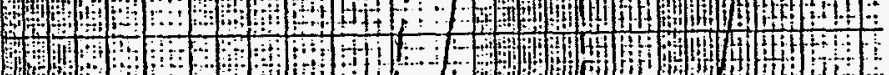

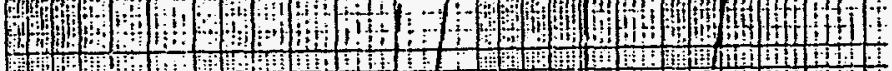

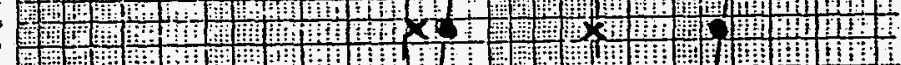

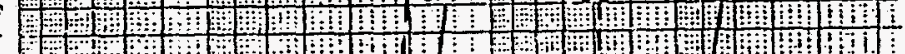

$10+4$ a

10 and

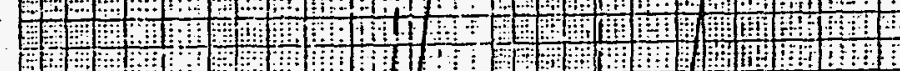

10 - 10 -

$\sim 20$ on

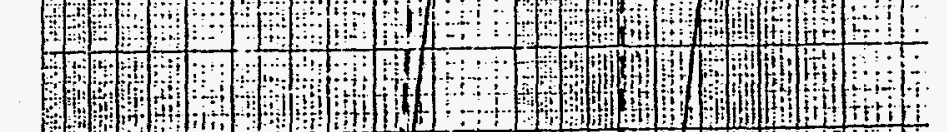

-2 .

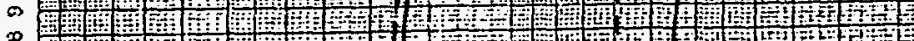



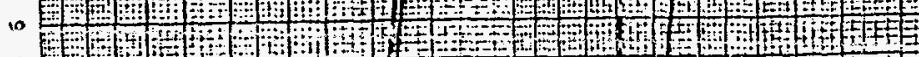

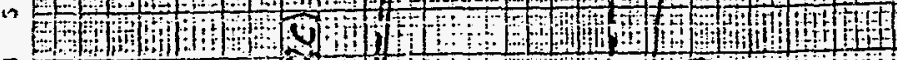

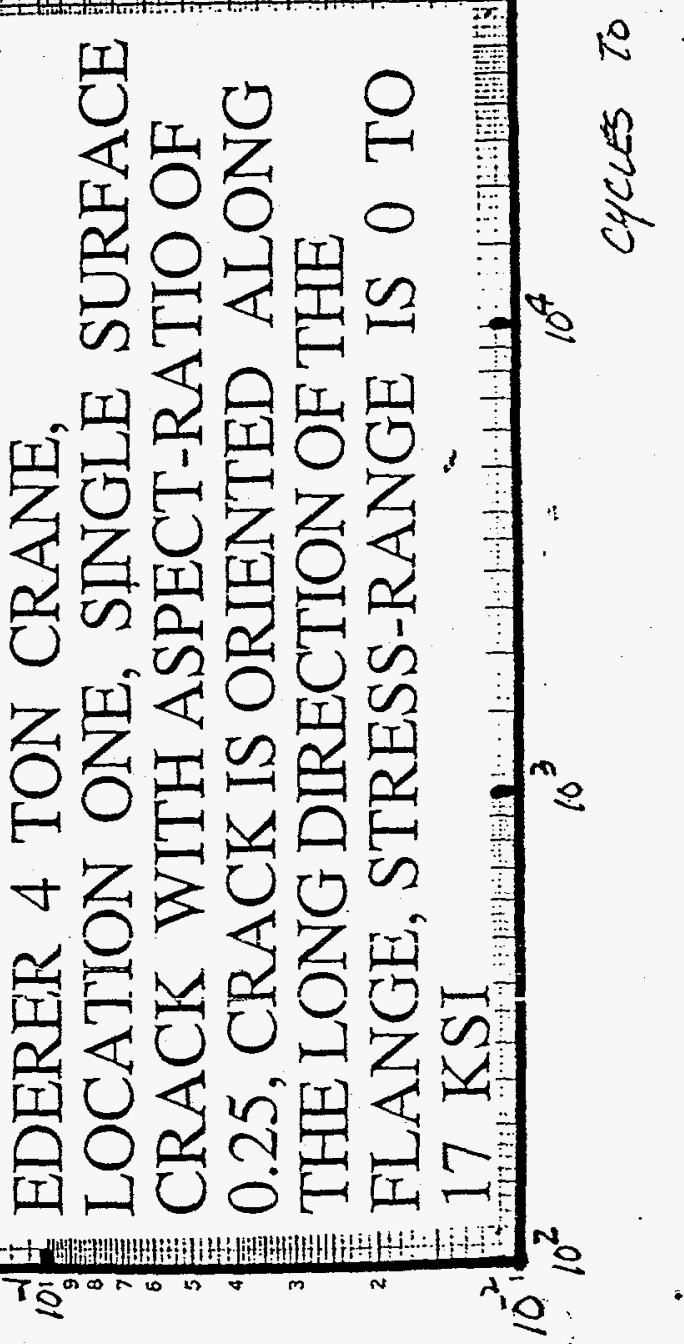

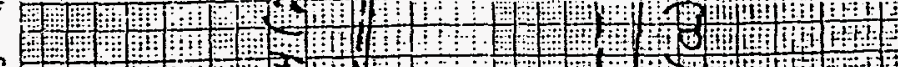

-

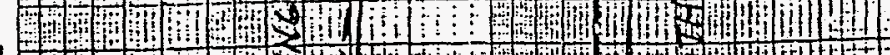

(1)

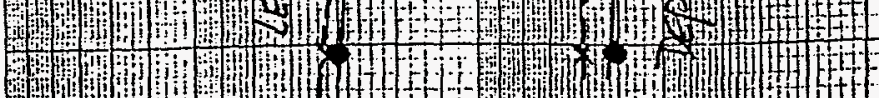




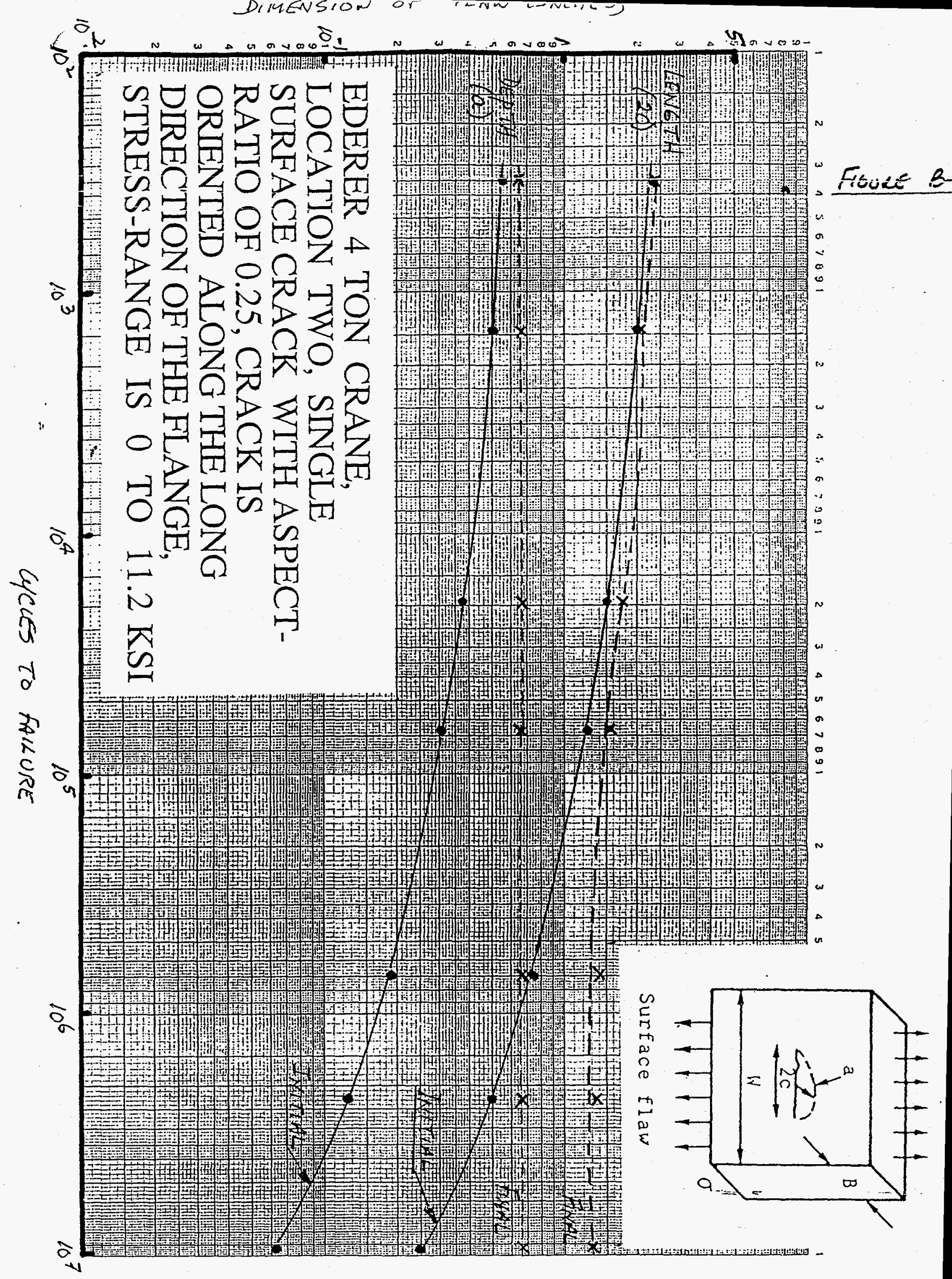

